\title{
10. ve 11. Asırda Kuzey-Batı İran'da Etkili Olmuş Bir İslam Hanedanı: Hasanveyhler (956-1048)*
}

\author{
An Islamic Dynasty Influenced in North-West Iran in the 10th and 11th Century: Hasanwayhs (956- \\ 1048)
}

\section{İbrahim GÜNEȘa}

Doktora Öğrencisi, Muğla Sitkı Koçman Üniversitesi, Tarih Bölümü,Muğla, ibrahimgn01@gmail.com. ORCID: 0000-0002-2080-8870

\section{$\ddot{O Z Z}$}

Bu makalede 10. ve 11. asırda el-Cibâl ve Yukarı Cezire bölgesinde hüküm sürmüş Hasanveyh hanedanının siyasi tarihi incelenmiștir. Hasanveyh hanedanı Kürt asıllı olup birçok Kürt aşiretini de bünyelerinde barındırmıştır. Kurucusu Hasanveyh b. Hüseyin el-Kürdî olup Berzikânî aşiretine mensup bir şahsiyetken, bölgede etkin bir rol üstlenip kısa sürede birçok yeri zapt etmiştir. $\mathrm{Bu}$ hanedan hakimiyetleri boyunca Büveyhilere tabi olarak varlık göstermişlerdir. Ayrıca hâkimiyetleri süresince de bu hanedanın bölgedeki yayılışları ile komşu devletler ve emirliklerle olan ilişkileri açıklanmıștır. Bu hanedan, özellikle el-Cibâl olarak bilinen Batı İran'da kuruldukları süreçte bölgenin siyasetinde oldukça etkin rol oynamışlar, Hasanveyh ve Bedr gibi çok güçlü hükümdarlar çıkardıkları gibi hayır işleriyle de bilinmektedirler.

Anahtar Kelimeler: Hasanveyhler, Büveyhiler, Kürtler, İran, el-Cibâl Bölgesi.

\begin{abstract}
In this article the political history of the Hasanwayhs dynasty ruling in the al-Cibâl and Upper Cezire region in 10th and 11th century. Hasanveyh dynasty is of Kurdish origin and has many Kurdish tribes. While his founder Hasanveyh b. Hüseyin al-Kürdî was a member of the Berzikânî tribe, he took an active role in the region and captured many places in a short time. Throughout their dynasty, they were subordinated to the Buhevids. Also, expension of this emirate as well as relations with neihboring states and dynasty during their ruling have been presente. This dynasty, played a very activite role of the known al-Cibal in region Western Iran especially during the period $f$ the foundation, very powerful rulers such as Hasanvayh and Bedr come out with charity as well.
\end{abstract}

Keywords: Hasanweyhs, Buyids, Kurds, Iran, Region al-Cibâl.

\section{GİRIS}

Hasanveyhler, Sermâc Kalesi ${ }^{1}$ payitaht olarak kurulan ve 956-1048 yılları arasında Cibâl bölgesi ile el-Cezire bölgesinin kuzeydoğu kısımlarının bir bölümünü de kapsayan ve Büveyhilere tabi olarak yaşam alanı bulan bir İslam hanedanıdır. Adını Hasanveyh b. Hüseyinel-Kürdî el-Berzikânî'den almaktadır (Şeref Han, 1860, I: 20-21; Katib Çelebî, 1376: 301; Müneccimbaşı, 1285, II: 503).

Hasanveyh Hanedanının kökeninin Berzikânî Kürt aşiretinden geldiğini bilmemize rağmen, hanedanın hangi tarihten itibaren söz konusu bölgede etkili olduklarını ise kestirmek zordur. Hasanveyhlerin birçok Kürt aşiretini bünyelerinde barındırmaları ve bu aşiretlerin onlara sadık kalmaları da bölgede eskiden beri etkili olduklarını göstermektedir. Nitekim birçok Kürt aşiretini bünyelerinde toplamaları ve bunu yaparken bölgenin de huzur ve güvenliğini sağlamaları da onların eskiden beri bölgede etkili olduklarını veya tebaaları tarafından saygı duyulduklarını bize göstermektedir. Öte yandan Hasanveyhlerin, elCibâl bölgesini hangi statüde ellerinde tuttuklarına gelince, maalesef kaynaklarda geçen bilgiler bir hayli karışık olup verilen bilgilerde de bir açıklık yoktur. Bunların Büveyhiler'e tabi olarak bölgeyi kontrol ettikleri bilgimiz dâhilindedir. Lakin geniş bir

\footnotetext{
${ }^{1}$ Hemedân ve Huzistân arasında ve bugünkü Bisulun Dağı’nın güneyinde yer alan bir kaledir. Bkz: Yakut el-Hamavî, 1988, III:215; Yasmî: 182.

* Bu makalede bilimsel araştırma ve yayın etiği ilkelerine uyulmuştur. / In this article, the principles of scientific research and publication ethics were followed.
} 
alanda hayır ve imar işlerinde ün kazanmaları ve çevredeki siyasi meselelere müdahil olup bazı toprak kazançları sağlamaları ise Hasanveyhlerin bir aşiret yapılanmasından daha büyük bir siyasi oluşum olduklarını göstermektedir. Ayrıca tetkikimize kaynaklık eden eserler, dönemin Abbasi halifesinin Bedr b. Hasanveyh'e "Nasırü'd-Devle" lakabı ile sancak verdiğini ve kendi adlarına para bastıklarına dair bazı önemli kayıtları ihtiva etmektedirler. Bu sebeple Hasanveyhlerin bir nevi bağımsızlık statüsüne ulaştıkları ihtimali akla getirmektedir. Fakat bunların Büveyhilere tabi olduklarını bildiğimizden Hasanveyhlerin bağımsız bir yapıya ulaştıkları hükmü dönemin siyasi realitesinde mümkün gözükmemektedir. Hasanveyhler, her halde bir kaleye ve onun çevresinde bulunan bazı ufak şehirleri kontrol eden özerk bir yerel emirlik yapılanmasından daha büyük bir siyasi teşekkül kurmamışlardır.

\section{HASANVEYHLERİN KURULUŞU VE HASANVEYH DEVRİ (956-980)}

Hasanveyhlerin el-Cibâl bölgesindeki hakimiyetleri 956 yılında başlamakta olup (Hidayet, 1373: 85) hanedanın kurucusu ve ilk hükümdarı Hasanveyh² (Ebü'l-Fevâris) b. Hüseyin el-Kürdî el- Berzikânî'dir. Kaynaklar, bunların Kürt oldukları hususunda ittifak ederler. Hasanveyh'in annesi Ayşâniyye Kürt aşiretinden iken, babası Hüseyin el-Kürdî el-Berzikânî, Berzeniyye diye adlandırılan Kürt aşiretine mensup olup bu aşirete liderlik ve komutanlık etmekteydi. Vefat edince aşiretin başına oğlu Hasanveyh geçtmiştir. Kendisi Hemedân'da yer alan Sermâc Kalesi'ni payitaht yaparak dönemin en büyük İslam devletlerinden biri olan Büveyhîlerin içinde yaşanan iktidar mücadelesinde, gâh taraf tutmuş gâh da devletin içine düştüğü zaaflardan faydalanarak kısa sürede hanedanını kuvvetlendirmeyi başarmıştır. Bunların yanında Rüknüddevle'nin Horosân seferi sırasında Büveyhî liderin yanında bulunmasından ötürü bu hükümdarın tevcihini kazanmıştır (İbnü'l-Miskeveyh, 2003, V: 371-372; İbnü'l-Esîr, 1987, VII: 388; İbn Haldûn, 2006, IV: 615; Şeref Han, 1860, I: 21; Ruhanî, 1371: 41-42 ).

Hasanveyh, Rürknüddevle'nin devlet işleriyle uğraşmasını firsat bilerek iktidarını el-Cibâl bölgesinde bir hayli genişletip güçlendirmiştir. Hasanveyh, kısa bir süre içinde başta Hemedân ve Dinever olmak üzere bölgedeki pek çok önemli şehir ve mıntıkayı ele geçirmiştir. Hasanveyh'in Vendâd b. Ahmed ve Gânim b. Ahmed adında iki dayısı bulunmaktaydı. Bunlar emirlerinde binlerce muharip asker olmasının yanında Ayşâniyye aşiretinin komutanları ve liderleriydiler. Bu aşiret Nihâvend, Dinever, Hemedân, Samagân, ve Azerbaycân'dan Şehruzur'a kadarki alanı 50 yıl boyunca (911-961) ellerinde tutarak burayı yönetmişlerdi. Bunlardan Gânim b. Ahmed 961 yılında vefat edince yerine oğlu Ebü Salim Deysem geçmişti. Kendisi Büveyhî veziri İbnü'l-Amîd elindeki Kasnân, Ganimabâd ve diğer kaleleri elinden alana kadar Kasnân'daki kalesinde topraklarının yönetmişti. Hasanveyh'in diğer dayısı olan Vendâd b. Ahmed 960 yılında vefat edince yerine oğlu Ebü'l-Ganâim Abdülvahhâb geçti ise de kendisi Şazencân Kürtleri tarafından esir edilip Hasanveyh'e teslim edilmişti. Böylece Ebü’l-Ganâim Abdülvahhâb'a ait olan tüm topraklar ve mallar Hasanveyh b. Hüseyin el-Kürdî el- Berzikânî'nin eline geçmiştir (İbnü'l-Esîr, 1987, VII: 388; İbn Haldûn, 2006, IV:615; Ruhanî,1371:41-42).

Anlaşılan o ki, o dönemde Hasanveyh'in yoldan geçen kervanlara saldırdığına dair şikâyetleri Büveyhî lideri göz yummaktaydı. Aynı tarihlerde Horasan orduları, Deylemliler üzerine sefere çıkınca Hasanveyh de Deylemlilerin safında savaşın onları himaye etmişti. Fakat bir olay yüzünden Büveyhi hükümdarı Rüknüddevle ile Hasanveyh’in arası açılmıştır. Nitekim Musaffîroğulları'ndan Sehlân b. Musaffîr 970 yılında bir antlaşmazlık yüzünden Hasanveyh üzerine yürümüştür. Fakat Sehlân b. Musaffir, Hasanveyh önünde bozguna uğramış ve ordusunun geri kalan bölümünü açık bir yerde toplamak zorunda kalmıştı. Hasanveyh de karşı saldırıya geçerek Sehlân b. Musaffir'i ve askerlerle komutanlarını kuşatmıştı. Hasanveyh etrafta topladığı büyük diken yığınlarını Sehlân b. Musaffir ve ordusunun bulunduğu alanın çevresine yığarak bu dikenleri ateşe vermiştir. Dikenlerin ateşe verilmesiyle oluşan alevler, yaz sıcaklığıyla birleşince Musaffir'i ordusu helak olmuştur. Ordusunun yok edildiğini gören Sehlân b. Musaffir ise mecburen Hasanveyh’ten aman dilemiş, askerleri ile birlikte teslim olmuştur. Bu haberin duyulması üzerine Rüknüddevle, 970 yılında Hasanveyh üzerine veziri İbnü'l-Amîd komutasında bir ordu göndermiştir. İbnü'lAmîd sefere çıkarken yanına oğlu Ebü'l-Feth'i de almıştı. Fakat İbnü'l-Amîd, ordusu ile birlikte Hemedân'a ulaştığında vefat dince ordunun kontrolünü oğlu devralmıştır. Ebü'l-Feth, ordunun ağırlıkları ile şehre girdiğinde Hasanveyh onu karşılayarak kendisine 50.000 dinar vergi vermek şartı ile bir antlaşma imzalamayı başarmıştır. Hasanveyh ile anlaşan Ebü’l-Feth böylece Rey’e geri dönmüştür (İbnü'l-Miskeveyh, 2003, V: 372; İbnü’l-Esîr, 1987, VII: 319-320; İbn Haldûn, 2006, IV:615; Ahmed Gaffarî Kâzvînî:167-168; Cahen, 1986: 258).

Büveyhî lideri Rüknüddevle, vefat etmeden önce en büyük oğlu Adududevle'yi kendine varis bırakırken, diğer oğullarından Fahrüddevle'ye Hemedân ve el-Cibâl bölgesini, küçük oğlu Müeyyeddüdevle'ye ise İsfahân ve çevresini vererek kendilerinin ağabeyleri Adududevle’ye tabi olmalarını istemişti (İbnü'l-Esîr, 1987, VIII: 364). Bunun yanında Rüknüddevle'nin kardeşi Muizzüddevle'nin oğlu olan Bahtiyar, o sıralar Irak bölgesinde yöneticilik yapmaktaydı. Fakat yeğeninin açıktan açığa en büyük oğlu Adududevle'ye karşı husumeti bulunmaktaydı. Hasanveyh ise hanedan içinde yaşanan bu çekişmelerde Bahtiyar'ın tarafinı tutuyor ve bir savaş durumunda kendisine yardım edeceği hususunda güvence veriyordu. Ayrıca Bahtiyar'ın safında Hasanveyh dışında o dönemin gözde yöneticilerinden Fahrüddevle b. Rüknüddevle, Ebü Tağlib b. Hamdân, İmran b. Şahin ve birçok emir bulunmaktaydı. Nihayetinde aralarındaki husumet iyice derinleşince, Adududevle 977 yılında Irak'a Bahtiyar üzerine yürüdü. Durumunun kötüye gittiğini anlayan Bahtiyar ise derhal kendi sözünü pek dinlemeyen ve kendisini sürekli Adududevle'ye karş1 kışkırtan İbn Bakıyye'yi tutuklayarak Adududevle nezdinde sulh teşebbüsünde bulundu. Hasanveyh de bu gelişmeler karşısında söz verdiği gibi iki oğlu Abdürrezzâk ve Bedr komutasında bir süvari birliğini yardıma gönderdi. Lakin Adududevle ve Bahtiyar

\footnotetext{
${ }^{2}$ Hasanveyh ismi bu hanedan dıșında İran bölgesinden el-Cezire bölgesine kadar geniş bir coğrafyada kullanıldı̆̆ görülmektedir. Fakat söz konusu isim kaynaklarda Hasnûn- حسنون (İbn Mustevfi, 1980, I: vr.22a, ), Hasveyh - حسويه (İbn Belhî, 1921:128 vd; Şirazî,1350: 61,63) ve Hasanveyh- هنوئ (Kirmî,1373: 229-232; Zekeriya Kâzvinî, 1373: 509; Tahrir Tarih-i Vassaf, 1383:232; Hafiz Ebru, 1378, II, vd; İsfehânî, 1990, I:200, 444, II: 216; Kumî, 1385:613; Fesaî, 1367, I: 237 vd ) gibi farklı şekillerde yazılmaktadır.
} 
arasında ciddi bir savaş olmadığından Hasanveyh'in ordusu da bir çatışmaya girmeden geri döndü (İbnü'l-Miskeveyh, 2003, V:426-429, 432; İbnü’l-Esîr, 1987, VII:365-366; Mustevfî, 1387:421)³.

Hasanveyh, 980 yılında vefat etmiştir (İbnü'l-Cevzî,1992, XIV:272; İbnü’l-Esîr, 1987, VII:388; Ahmed Gaffarî Kâzvînî:168; Hidayet, 1373:88). Geride Ebü'l-Ala, Abdurrezzak, Bedr, Asâm, Ebü Adnân, Bahtiyâr ve Abdülmelik adında yedi oğul bıraktı. Hasanveyh son derece akıllı bir insan olup dönemin karışıklıklarından faydalanıp emirliğini genişletmeyi çok iyi bildi. Ayrıca çok iyi bir asker adamı olduğu da şüphe götürmez. Hanedanının dâhili siyasetini son derece mazbut bir şekilde yürütmesinin yanında harici meselelerde akıllıca davranmayı ihmal etmedi. Dönemin kaynakları kendisinin çok iyi bir devlet adamı olduğunu ve yöneticiliğinde de işlerini tam bir otorite içinde yürüttüğünü dile getirirler. Ayrıca tüm kaynaklarımız ondan övgü ile bahsetmekten de geri kalmamışlardır. Emri altındaki tüm adamlarını iyilik yapmaları hususunda teşvik eder, kötülük yapmamaları hususunda da birçok yasak koyardı. Askerlik ve yöneticilikteki başarılarını, zamanının insanlar tarafından en fazla sevilen liderlerinden biri olmaya vesile olan hayır işleriyle süslemeyi çok iyi başarmıştır. Nitekim Mekke ve Medine halkına yüksek miktarda ihsanlarda bulunmuş ve toprakları üzerindeki insanların refahı noktasında elinde geleni yapmıştır. Devlet işlerindeki üstün meziyetleri dışında da imar işleriyle yakından ilgilendiğini Sermâc Kalesi'ni simetrik şekillerde inşa etmesinden ve aynı tarzda Dinever şehrinde bir cami yaptırmasından anlayabiliyoruz. Şüphesiz kendisi döneminin en dikkat çeken yöneticilerinden birisiyken, hayır işlerinden de zamanının önde gelen şahsiyetlerindendi (İbnü'l-Miskeveyh, 2003, V:451; İbnü’l-Esîr, 1987, VII: 388; Hândmir, 1362, II: 438; Ruhanî,1371: 42; Yasmî:183).

\section{EBÜ NECM BEDR DEVRİ (980-1015)}

Hasanveyh'in vefatı üzerine oğulları birbirlerine düşmüşlerdir. Bunlardan bir kısmı Fahrüddevle'nin, diğer bir kısmı da Adududevle'nin yanına giderek yardım istemişlerdir (İbnü'l-Esîr, 1987, VII: 388; İbn Haldûn, 2006, IV: 615; Ruhanî,1371:43). Bunlardan Bahtiyâr, Adududevle'ye mektup yazıp emrine girdiğini beyan ederek hanedanın merkezi olan Sermâc Kalesi'ni de elinde tutmayı başarmıştır. Fakat kısa bir süre sonra fikrini değiştirecek ki, Adududevle'nin itaatinden çıkmıştır. Bu sebeple Adududevle kalabalık bir orduyu Sermâc Kalesi üzerine sevk etmiştir. Ordu hızlı bir yürüyüşten sonra önce Nihâvend daha sonra da Dinever’i ele geçirmiştir. Kısa süre sonra da ordu Sermâc Kalesi önünde görünerek bölgede bulunan birçok mevkii tahrip ettiler. Uzun bir kuşatmanın ardından nihayetinde kale düştü ve bu kale ile birlikte Bahtiyar ve kardeşlerinin elinde bulunan diğer tüm kalelerde de Büveyhî ordusunun eline geçmiştir. Kale içinde bulunan muazzam miktardaki mal ve zahire ise Büveyhî ordusu tarafından yağmalanmıştır (İbnü'l-Esîr, 1987, VII:388; Ebü'l Fidâ, 1997, I:464; İbnü'l-Verdî, 1996, I, 294; İbn Haldûn, 2006, IV:615-616; Hândmir, 1362, II: 438; Cahen, 1986:258).

Adududevle, bu şekilde Hasanveyhleri cezalandırmışsa da, topraklarını ellerinden almayarak hâkimiyetleri altında olan tüm bölgeleri onlara tekrar geri verdiğini görmekteyiz. Bunun yanında Hasanveyh'in oğullarından Ebü Necm Bedr'i de hanedanın başına getirtti. Nitekim Hasanveyh'in oğulları ellerindeki toprakların tümünün ellerinden çıktığını görünce Adududevle'nin huzuruna çıkarak af dilediler, Büveyhi lideri kendisine mukavemet eden Abdürrezzâk, Ebü'l-Ala ve Ebü'l-Adnan'1 tutuklatmıştır. Bedr, Asım ve Abdülmelik'e ise hilat giydirerek bunlardan Bedr'e Kürtlerin yaşadığı yerlerin yönetimini vermiştir (İbnü'l-Esîr, 1987, VII:388; İbn Haldûn, 2006, IV:616).

Her ne kadar Bedr ile birlikte Asım ve Abdülmelik, Aladududevle'nin ilgisine mazhar olduysalar da, bu defa bu iki kardeşten Asım büyük kardeşi Bedr'e karşı ayaklandığını görmekteyiz. Asım, Bedr'e karşı husumetleri bulunan diğer Kürt topluluklarını da yanına alarak ağabeyine karşı isyan etmiştir. Patlak veren bu isyan yayılıp Adududevle'nin kulağına gidince Büveyhî lideri derhal tam donanımlı bir orduyu Asım üzerine gönderdi. Bedr’in yardımına gelen Büveyhî ordusu isyanı kanlı bir şekilde bastırıp Asım ile birlikte bir takım adamlarını yanlarına alarak Hemedân'a götürüldüler ve bu adamlar büyük bir ihtimalle de burada infaz edildiler. Nitekim kaynaklarımız bir daha ondan haber alınmadığını yazarlar. Ayrıca Aladududevle, Hasanveyhlerin kendilerine sorun çıkaracağını tahmin edecek ki, 981 yılının başlarında Bedr dışındakilerin tümünü öldürtmüştür (İbnü'l- Esîr, 1987, VII:393; İbn Haldûn, 2006, IV:616).

Bedr, tıpkı babası gibi devrin siyasi çatışmalarından faydalanmayı çok iyi bilmiştir. Nitekim Adududevle'nin 982 yılında ölmesi üzerine kendisinin İran'a hâkim olan Şerefüddevle'nin itaatinde olduğunu haber vermiştir. Böylece Büveyhîlere sadakatini bildirerek hanedanını güvence altına almıştır. Fakat kısa bir süre sonra Fahrüddevle'nin yanında olmanın kendisi ve tebaası için daha faydalı olacağını hesap edecek ki, bu defa onun safına geçmiştir. Bedr'in bu durumunu haber alan Şerefüddevle de 987 yılında büyük kumandanlarından Karatekin el-Cehşiyânî’yi Hasanveyhler üzerine göndermiştir. Ayrıca kaynaklarımız Fahrüddevle'nin Karatekin el-Cehşiyânî’nin başıboş davranışlarından bıktığı için onun Bedr üzerine gönderdiğini ve bu vesile ile her ikisini bu şekilde birbirlerine vurdurarak onlardan kurtulmayı umduğunu yazarlar (Rûzrâvarî, 2003, VI:85; İbnü'l-Esîr, 1987, VII:430; İbn Haldûn, 2006, IV:616; Tatavî, 1382, III:1947).

Durumdan haberdar olan Bedr ise derhal gerekli hazırlıkları yapıp tüm Kürt savaşçılarını toplamıştır. Kısa bir süre sonra da Karatekin el-Cehşiyânî komutasındaki birliklerle Hasanveyhlerin topraklarını süratle işgal etmiştir. Hasanveyhler hükümdarı derhal askerleri ile harekete geçince iki ordu Karmısîn (Kirmânşâh) vadisinde karşılaşmış, Bedr başta sahte ricat yaparak mağlup olduğu izlenimini vererek geri çekilince de Karatekin el- Cehşiyânî ordusu ganimet hırsıyla savaş nizamını bozmuş ve Hasanveyhlere ait çadırlarına hücum etmiştir. Bunun üzerine, Bedr süratle arkadan vurup düşmanı kuşatması galip gelmesine yetmiştir. Nihayetinde Karatekin el-Cehşiyânî ordusu ile birlikte müthiş bir bozguna uğrayarak ordunun çoğu savaş meydanında

\footnotetext{
${ }^{3}$ Ayrıca Adududevle ile kardeşi Fahrüddevle arasındaki husumetin bir nedeninin de Hasanveyh olduğuna dair bazı kayıtlar mevcuttur. Bkz: İbnü’l-Esîr, 1987,
} VIII, s.389. 
imha edilmiş ve birçok kişi esir olarak ele geçirilmiştir. Bedr bu galibiyetten sonra Büveyhilerin elindeki Karmısîn ve Hulvân şehirlerini ele geçirmiştir. Karatekin el-Cehşiyânî ise bazı hususi hizmetkârları ile kurtulmayı başardıktan sonra, süratle bir şekilde Nehrevân köprüsünü geçip hezimetten kurtararak etrafa dağılan bazı askerleri ile birlikte Bağdad'a geri dönmüş, fakat burada bir suikasta uğrayarak öldürülmüştür (Rûzrâvarî, 2003, VI:85-86; İbnü’l- Cevzî,1992, XIV:322-323; İbnü'l-Esîr, 1987, VIII:430; İbn Haldûn, 2006, IV:616; Tatavî, 1382, III:1947-1948 )

$\mathrm{Bu}$ gelişmeden sonra durumunu iyice kuvvetlendiren Bedr, bu hadiselerden sonra daha aktif siyaset izleyerek bölgedeki siyasi meselelere müdahil olduğunu görmekteyiz. Büveyhîlerden Amîdü'l-Cuyuş, Horasân yolunun güvenliğine Bedr'in en büyük hasımlarından Ebü'l-Feth Annazî’ye verince, kendisi de derhal Amîdü'l-Cuyuş’un düşmanlarından Ebü’l-Cafer'i yanına çekerek 1007 yılında bünyesinde Emir Hindi b. Sadi, Ebü İsa Şadi b. Muhammed, Verrâm b. Muhammed ve birçok başarılı komutanın da olduğu bir orduyu Bağdad üzerine göndererek söz konusu atamanın öcünü almak istemiştir. Arkasından Emir Ebü'l-Hasan Ali b. Mezyed el- Esedî de Bahaüddevle'ye kırgınlığı yüzünden emrindeki askerlerle Bedir'in gönderdiği orduya katılınca, Ebü'l-Cafer el-Haccâc'ın komutasındaki ordunun mevcudu 10.000 süvariyi bulmuştur. Ordu tüm birlikleri ile Bağdad'a bir fersah uzaklıkta konaklayıp burada da yaklaşık bir ay kalmasına rağmen, Amîdü'l-Cuyuş, Bahaüddevle'nin düşmanlarından Ebü'l-Abbas b. Vasıl'ı mağlup edince komutanların da cesareti kırmıştır. Nitekim söz konusu tüm emirler muhtemel bir saldırıda yenilebileceklerini hesap edince dağıldılar. Böylece bu askeri harekât herhangi bir neticeye varmadan nihayetlenmiştir (İbnü'l-Esîr, 1987, VIII:39-40; İbn Haldûn, 2006, IV:617; Tatavî, 1382, III:2031).

Kısa bir süre sonra da Bahaüddevle, topraklarına saldıran Bedr üzerine Emîdü'l-Cuyuş komutasında bir ordu gönderdiyse de Bedr'in Emîdü'l-Cuyuş'a verdiği bazı telkinler işe yarayarak onunla savaşmadan bir antlaşmaya varmayı başarmıştır (İbnü'lEsîr, VIII:41-42).

Buna rağmen Bağdad seferi her ne kadar başarısız olduysa da, Bedr'in Ebü'l- Feth Annazî’ye karşı olan kini yatışmamıştır. Bedr, Hulvân ve Karmısîn bölgeleri fethedince Ebü'l-Feth Annazî, Rafi b. Makn'ın yanına sığınmıştır. Ayrıca o sıralar Rafi b. Makn de Dicle kenarında bazı şehir ve kaleleri elinde tutmaktaydı. Rafi b. Makn ile Bedr arasında bir dostluk olmasına rağmen, Rafi b. Makn'ın Bedr'in en büyük hasmını himaye edince iki hükümdarın arası açılmıştır. Her ne kadar Bedr, aralarındaki dostluğun devam etmesi için Ebü'l-Feth Annazî'yi yanından uzaklaştırmasını istedi ise de bu isteğini reddetmiştir. Bedr ise bu yüzden hazırlıkları tamamlayarak eski dostlarından Rafi b. Makn’ın üzerine ordusunu sevk etmiştir. Rafi b. Makn o sıralar Dicle nehrinin doğu cenahında elinde tuttuğu tüm şehirlerinin yağmalayarak Berecân Kalesini de ele geçirmiştir. Kalede bulunan hububat ateşe verildiği gibi etraftaki tüm su kuyuları doldurulmuştur. Böylece Hasanveyh hanedanın elindeki topraklar el-Cezire bölgesinin kuzey-doğu kısımlarını da içine alacak kadar genişlemiştir. Kaynaklarımız, bu olaydan sonra Ebü'l-Feth Annazî’nin Bağdad'a kaçıp Amîdü'l-Cuyuş tarafından hilat giydirildiğini ve ona yardım edilme sözü verildiğini rivayet ederler (İbnü’l-Esîr, 1987, VIII:40; İbn Haldûn, 2006, IV:617 ).

Bedr devrinde her ne kadar Hasanveyhler güçlenmişse de hanedan içindeki iç çekişmeler yüzünden büyük bir inkıraz yaşamıştır. Nitekim Bedr'in aslen Şazencân Kürt aşiretinden olan hanımından doğmuş Hilâl isminde bir oğlu vardı. Kaynaklarımız, Bedr'in Hilâl'i kendisinden uzak tuttuğunu ve bu sebeple babasının lütuf ve nimetlerinden diğer oğlu Ebü İsa'nın yararlandığını bildirirler. Buna göre Bedr, Hilâl'in annesinden ayrılmıştı ve anlaşıldığına göre de Hilâl'e her hangi bir yardımda da bulunmuyordu. Bir rivayete göre bir gün Hilâl babası ile ava çıkmış ve bir aslan avında Hilâl'in sertliğinden dolayı Bedr rahatsız olmuş ve hareketinden dolayı da oğlunu kendisinden uzaklaştırarak Memgân'ı kendisine ikta' olarak vermiştir. Fakat Hilâl burada kısa sürede güçlenerek kendi başına hareket etmeye başlamış ve içten içe babasına karşı öfke duyduğundan da iyice güçlenince babasının emirlerini dinlemez olmuştur. Kısa bir süre sonra da babasının yakın dostlarından Şehruzur hâkimi İbnü'lMazî'ye saldırmıştır. Bedr'in tüm tehditlerine rağmen elindeki tüm güçlerle İbnü'l-Mazî'nin topraklarına işgal ederek Şehruzur'u muhasara edip içindeki mallar ile birlikte zapt etmiş, İbnü'l-Mazî’yi ailesi ile birlikte kılıçtan geçirmiştir. Kaynaklar, bu olayın Bedr'in kulağına gidince oğlunun bu hareketine son derece üzüldüğüne ve kendisine de cephe aldığına bildirirler (İbnü'l-Esîr, 1987, VIII:55; İbn Haldûn, 2006, IV:617-618; Hândmir, 1362,II: 438).

Hilâl, Şehruzur'u ele geçirdikten sonra bu sefer babasının ordusunda yer alan asker ve komutanlara çeşitli ihsanlarda bulunarak kendi tarafına çekmeye başlamıştır. Bazı kaynaklar Bedr'in askerlerine cimri davrandığını ve buna karşın Hilâl'in lütuf ve ihsanlarını gören askerlerin ve halkın da onun tarafına geçtiğini kaydederler. Nihayetinde Hilâl'in bu yaptıkları Bedr için tahammül edilemeyecek bir noktaya gelince, 400 (1009) yılının başlarında oğlu üzerine harekete geçmiştir. Hilâl de aynı şekilde maiyetindeki birliklerle buna karşılık verince iki ordu Dinever şehri girişinde karşı karşıya gelmiştir. Hasanveyh ordusunda yer alan Kürtler, Hilâl'i safına geçmesi üzerine Bedr'in askerleri yenilmiş ve kendisi de esir alınarak Hilâl'in yanına götürülmüştür. Fakat Hilâl'in komutanları her ne kadar babasını öldürülmesini tavsiye ettilerse de Hilâl bunu şiddetle reddederek etrafındakilere böyle bir şeyi yapacak kadar isyankâr bir oğul olmayacağını söylemiştir. Bedr ise Hilâl'e artık hanedanın başına geçmesi gerektiğini ve kendisine de verilecek bir kalede ibadetle uğraşmak istediğini söyleyerek oğlunu ikna etmeye çalışmıştır. Neticede Hilâl, yanına biraz mal da vererek babasını serbest bırakmıştır (İbnü'l-Esîr, 1987, VIII:55-56; Mucmelü't-Tevarih, 1318:397-398; İbn Haldûn, 2006, IV:618; Hândmir, 1362, II: 438-439).

Bedr, oğlunun elinden serbest kaldıktan sonra derhal yerleştiği kaleyi tahkim ederek eski hasımlarından Feth b. Annaz ve o sırada Esedabâd'ta bulunan Ebü İsa Şadî b. Muhammed'e haber yollayıp Hilâl'in maiyetindeki topraklara saldırmalarını istemiştir. Bu iki emir de Bedr'in istediğini yaparak Ebü'l-Feth de bu niyetle Hilâl'e bağlı Karmısin'i ele geçirmişlerdir. Ebü İsa Şadî ise Sabur-Hast'da bulunan ve Hilâl'e ait silah ve malzemeleri yağmalayarak Nihâvend üzerine yürüdüyse de, Hilâl kendisine yetişerek ordusunu kırmıştır. Nihâvend'de bulunan Ebübekir b. Rafi de Ebü İsa Şadî’yi esir olarak ele geçirdikten 
sonra Hilâl'e teslim etmiştir. Fakat Hilâl bu değerli emiri cezalandırmayarak biraz mal verdikten sonra onu maiyetine almıştır (İbnü'l-Esîr, 1987, VIII:56; Mucmelü't-Tevarih, 1318:398-399; İbn Haldûn, 2006, IV:618 ).

Söz konusu seferin başarısızlıkla sonuçlandığını gören Bedr, bu defa Büveyhîlerden Bahaüddevle’den yardım talep etmiştir. Bahaüddevle de onun bu yardım talebini geri çevirmeyerek Fahrü'l-Mülk Ebü Galib komutasında bir orduyu 1010 tarihinde yardımına göndermiştir. Ebü İsa her ne kadar Hilâl'e bu ordu ile savaşmamanın ve Bahaüddevle'nin maiyetine girmenin daha iyi olacağını söylemişse de, Hilâl, bu teklifin babasına karşı yapılmış bir zaman kazanma olarak düşünerek Ebü İsa'yı öldürtmüştür. Ardından da derhal Sabur-Hast'a kadar ilerleyen Büveyhî ordusunun üzerine yürümüştür. Fakat Büveyhî ordusu beklediğinden daha kalabalık çıkınca, Fahrü'l-Mülk’e haber yollayarak itaatine girmek istediğini bildirmiştir. Büveyhî komutanı bu teklifi olumlu bulup durumu Bedr'e bir elçi ile haber yolladıysa da, Bedr buna çok öfkelenmiştir. Bir rivayete göre Bedr'in elçiye hakaret ederek Fahrü'l-Mülk'e de : "Bu zayıflı̆̆ını anlayan Hilâl'in bir aldatmacasıdır. Yapılabilecek en iyi iş ona nefes bile aldırtmamaktır" şeklinde bir uyarıda bulunmuştur. Bunun üzerine Fahrü'l-Mülk derhal ordusunu savaş düzenine sokarak Hilâl'in üzerine yürümüştür. Kısa sürede sonra da Hilâl'in ordusu bozguna uğratıp kendisini de esir almıştır (İbnü'l-Esîr, 1987, VIII:56-57; Mucmelü't-Tevarih, 1318:399-400; İbn Haldûn, 2006, IV:618; Hândmir, 1362, II: 439; Şeref Han, 1860 , I:22 ).

Hilâl ardından Fahrü'l-Mülk’ün yanına götürülerek onun huzurunda yeri öptürmüşlerdir. Ayrıca Hilâl, Fahrü'l-Mülk’e kendisinin babasına teslim edilmemesi istemiş, bu istek de Büveyhî komutanı tarafından kabul görmüştür. Fakat Hilâl'in oturduğu kale, içindeki değerli malzemelerle Bedr'e verilmiştir. Kaynaklar, kalede 40.000 kese dirhem, 400 kese de altın, çok güzel mücevherler, kıymetli elbiseler ve silahların olduğunu yazarlar (İbnü’l-Esîr, 1987, VIII:57; Mucmelü’t-Tevarih, 1318,s.400; İbn Haldûn, 2006, IV:618) .

Hilâl, böylece Büveyhîlere teslim olduktan sonra Bedr rahat bir nefes almıştır. Fakat bu defa 1014 yılında Hilâl'in oğlu Tahir bir zamanlar dedesi Bedr tarafından Amîdü'l-Cuyuş'a teslim edilen Fahrü'l-Mülk'ün askerleri ile savaşa girmiş ve şehri onlardan almaya muvaffak olmuştur (Ocak 1014). Amîdü'l-Cuyuş bu haberi alınca derhal Tahir b. Hilâl'e mektup yazarak muhasara esnasında esir aldığı askerleri serbest bırakmasını istemiştir. Tahir bu emre uyup esirleri serbest bıraksa da Şehruzur'u elinde tutmayı başarmıştır (İbnü'l-Esîr, 1987, VIII:81; Mucmelü’t-Tevarih, 1318:400; İbn Haldûn, 2006, IV:618 ).

Bedr, dâhili sancılı sürece geride bıraktıktan sonra tekrar çevre bölgelere saldırmaya devam etmiştir. Nitekim 1015 yılında payitahtı Küshad kalesi olan Hüseyin b. Mesud el-Kürdî’ye ait topraklara hücum etmiştir. Kaynaklarımız Bedr'in büyük bir stratejik hata yaparak kış mevsiminde bu sefere koyulduğunu ve bu yüzden de askerlerinin bu duruma çok kızdıklarını kaydederler. Gerçekte de bu askeri harekât, kış mevsiminde gerçekleşmişti ve ordu sefer esnasında helak olmuştur. Nihayetinde ise askerleri kendisine bir suikast düzenleyerek onu öldürmüşlerdir (İbnü'l-Esîr, 1987, VIII:82-83; Mucmelü't-Tevarih, 1318:400; İbn Haldûn, 2006, IV:619; Hândmir, 1362, II: 439).

Bedr'in nasıl öldürüldüğüne dair ayrıntılar kaynaklarda geçmektedir. Buna göre onun yakın adamlarından biri, askerlerinin onu öldürmeye niyetlendiğini ve bunu da gerçekleştirmek için de çalıştıklarını söylemiştir. Fakat Bedr buna kulak asmayarak tedbir alacağına "Bunu yapacak olan köpekler de kimmiş ?"şeklinde muvazenesiz bir cevapla adamı başından salmıştır. Sonunda Bedr bir tepeye çıkınca adamları onun üzerine saldırarak öldürmüşlerdir. İbnü'l-Esîr, Bedr'i öldüren taifenin el-Cevzekân Kürtleri olduğunu söyler. Bedr öldürülünce bu Kürt taifesi ordunun elindeki birçok eşyayı da alarak oradan ayrılarak Ebü Tahir b. Fahrüddevle b. Büveyh'in itaatine girmişlerdir. Fahrüddevle de kısa bir süre sonra durumdan istifade Bedr'in topraklarına saldırarak bazı mevkileri ele geçirmiştir. Bunun dışında, bir rivayete göre Hüseyin b. Mesud el-Kürdî söz konusu tepeye gelince Bedr'in cesedini açık bir yerde bulmuş o da onu kefenleyerek Hz. Ali’nin türbesine (Meşhed-i Ali) defnetmiştir. Öldügünde toprakları Sabur-Hast, Dinever, Berucird, Nihâvend, Esedabâd ve Ahvâz’a bağlı bölgeler ile bölgede bulunan birçok kaleyi içine almaktayd1. (İbnü'l-Cevzî,1992, XV:104-106; İbnü'l-Esîr, 1987, VIII:82-83; Mucmelü't-Tevarih, 1318:400-401; İbn Haldûn, 2006, IV:619; Ahmed Gaffarî Kâzvînî:168; Hândmir, 1362, II: 439). Ölümünden sonra ülkede düzenin bozulmas1 ve hırsız ve yağmacıların armasından dolayı, Dinever kadısı İbn Kec gibi meşhur bir âlim bu süreçte öldürülmüştür (İbnü'l-Kesîr, 1995, XII:66).

Yukarda görüldüğü üzere Bedr devrinde Hasanveyhler, Büveyhilere bağlı olmaya ve devlet içerisinde yaşanan birçok siyasi hadiselerin içinde de yer almaya devam ettiler (Reşî̉du'd-dîn, 1386:32, 106, 154; Fakîhî, 1378:53). Kaynaklarımız Bedr'in bölgesinin seçkin liderlerden biri olmasının yanında, iyi bir devlet adamı ve iyi bir siyasetçi olduğunu kaydederler. Adına para bastırmış (Heyet, 2014:39), dönemin halifesi Kadir-billâh de kendisine Ebü Necm (yıldızların babası) künyesini takmış ve Nasırü'd-Devle lakabı vererek ona bir sancak hazırlamıştır (Utbî, 1858:424; Carbazekânî, vr.146; İbnü’l-Cevzî, 1992, XV:8,104; Mucmelü't-Tevarih, 1318:401;i̇bn Tagrîbirdî, 1992, IV:237; Ahmed Gaffarî Kâzvînî:168; Hândmir, 1362, II: 438; Tatavî, 1382, III:2055; Katib Çelebî, 1376:318). Rûzrâvarî, onun Allah yolunda gaza etmek için 20.000 süvarisi olduğunu söyler. Kendisi yoksullara çok yardım eder, hayır ve hasenat konusunda elinden geleni yapardı. Kaynaklar onun her Cuma günü yoksul ve dullara 20.000 dirhem sarf ettiğini söyleyerek ayrıca kendisi her ay ölüleri kefenlemek için de aynı şekilde 20.000 dirhem harcadığını kaydederler. Ayrıca her sene Mekke ve Medine'de mücavir olarak yaşayan kimselere sadakat dağıtmak, atölyeleri onarmak, haç yolundaki su kaynaklarını sslah etmek ve yeni su kuyuları kazdırmak için 100.000 dinar sarf eder, Hemedan ve Bağdad'ta yolda kalmış kimselere ayakkabı yapmaları ve bineklerin atlarına nal yapmak için ayakkabı üreticilerine ve nalbantlara 3000 dinara yakın para verdiğine dair elimizde kayıtlar mevcuttur (Rûzrâvarî, 2003, VI:172-173; İbnü'l-Cevzî,1992, XV:46,104-106; İbn Tagrîbirdî, 1992, IV:171, 237; Ahmed Gaffarî Kâzvînî:168) Bunun yanında Bedr, annesi ve Adududevle adına her yıl yirmi kişiyi Hac'a gönderir, bunlar için yaklaşık 1.000 dinar harcardı. Kendi döneminde sayısı 2000'i aşan mescit ve han inşa ederek var olanları da tamir ettirmiş, bunların dışında da fakihlere, kadılara, müezzinlere, eşrafa, şehitlere, yoksullara, düşkünlere, dul, yetim ve öksüzlere maaş bağlamıştır. Ayrıca kendisinin çok namaz kılan birisi olup çok zikir yapardı. Öldüğünde 
yaşı seksen civarı idi ve gerisinde birçok şehir ve mülk yanında 140.000 dinar ve 40.000 küsur dirhem de miras bırakmıştır (Rûzrâvarî, 2003, VI:172-173; İbnü’l-Cevzî,1992, XV:105; Tatavî, 1382, III:2055-2056).

\section{HASANVEYH İKTİDARININ YIKILIŞI (1015-1048)}

Dedesinin ölüm haberini alan ve o sıralara Şehruzur'da bulunan Tahir b. Hilâl, hanedanın başına geçmek için süratle harekete geçtiyse de, Büveyhî Şemsüddevle'nin gönderdiği ordunun önünde büyük bir bozgun yaşayarak esir düşmüştür. Fakat babası Hilâl'in naibi onu yanına alarak Hemedân'a giderek Tahir'in öldürülmesine mani olmuştur. Burada bulunan el-Luriyye ve eşŞazencan Kürtleri ile birlikte Ebü Feth b. Annaz'ın oğlu Ebü'ş-Şevk'in yanına gitmiştir (İbnü'l-Esîr, 1987, VIII:83; Mucmelü’tTevarih, 1318:401-402; İbn Haldûn, 2006, IV:61 ).

Hilâl ise o sıralar babası ile girdiği mücadelede esir alındığından, bu hadiseleri hapsolduğu yerden izliyordu. Fakat bu defa Büveyhîlerden Sultanüddevle, Şemsüddevle'nin Bedr'in topraklarına saldırdığını duyunca Hilâl'i kapalı tutulduğu yerden serbest bırakmış, kendisine de asker ve silah vererek Şemsüddevle'nin üzerine göndermiştir. Hilâl, emrinde ordu ile harekete geçince Şemsüddevle'nin ordusu ile karşılaşmış ve mağlup olmuştur (Nisan-Mayıs 1015). Ordusu yok olduğu gibi kendisi de Ebü'l-Muzaffer Anuştekin el-Arabî gibi komutanlarla esir düşmüştür. Kısa bir süre sonra da öldürülmüştür (İ̉bnü’l-Esîr, 1987, VIII:83; Mucmelü’t-Tevarih, 1318:401-402; İbn Haldûn, 2006, IV:619; Ahmed Gaffarî Kâzvînî:168; Katib Çelebî, 1376:318).

Tahir b. Hilâl ise Hemedân'a götürüldükten sonra Büveyhîler'e itaat edeceği sözüne mukabil Şemsüddevle tarafından serbest bırakılmıştır. Fakat Tahir kendi etrafında toplanan askerle iyice güçlenince bu kez Ebü’ş-Şevk ile arası bozulmuştur. Kısa sürede sonra Tahir ile Ebü'ş-Şevk savaşa tutuşarak Ebü'ş-Şevk Tahir önünde yenilmiştir. Ebü’ş-Şevk tekrar Tahir'e saldırdıysa da, aynı şekilde yine bozguna uğramış ve Hulvân'a çekilmek zorunda kalmıştır (1015). Kaynaklar her ne kadar burada bulunan Ebü'l-Hasan b. Mezyed el- Esedî'nin Tahir'e karşı ona yardım edeceği teklifinde bulunmuşsa da, Ebü'l-Şevk'in tekrar savaşa girecek kadar güçlü olmadığını kaydederler. Tahir ise Nehrevân'a giderek burada ikamet etmeye başlamıştır. Burada Ebü'lŞevk'e haber yollayarak onunla bir antlaşma imzalamış ve onun kız kardeşi ile de evlenmiştir. Kaynaklarımız Tahir'in bu suretle Ebü’ş-Şevk’ten emin olmak istediğini söylerler. Fakat Ebü’ş-Şevk kısa bir süre sonra üzerine hücum etmiş ve yapılan çatışmada Tahir öldürülmüştür. Cesedi ise adamlar tarafından Bau't-Tebn'e götürülerek buradaki bir türbeye defnedilmiştir (İbnü’l-Esîr, 1987, VIII:91; İbn Haldûn, 2006, IV:619-620; Ahmed Gaffarî Kâzvînî:168; Şeref Han, 1860, I:22-23; Cahen, 1986:258). Böylece Hasanveyhlerin bölgedeki iktidarı son bulmuş ve onlara ait topraklar da Ebü’ş-Şevk idaresindeki bir diğer Kürt hanedanı olan Annazilerin kontrolüne girmiştir(1016). Tahir'den sonra Bedr b.Tahir ve Ebü Mansur Hasanveyh el- Berzikanî ve Ebü Salem Deysem el-Berzikanî gibi Hasanveyh soyundan gelen bazı şahıslar el-Cibâl bölgesinde Annazilere tabi olarak yaşamışlardır (Ruhanî,1371:47).

Bunun yanında birçok kaynak Annaziler devrini Hasanveyhler tarihi içine katarlarsa da, biz Hasanveyh sülalesini temel aldığımızda bu hanedanın bölgedeki iktidar ömrünün 1048 yılında son bulduğu söyleyebiliriz. Nitekim ellerinden kalan son toprak parçası Sermâc kalesinin 1048 yılına kadar Hasanveyh sülalesinin yönettiğini biliyoruz. İbnü'l-Esîr, 439 yılı olaylarını anlatırken Bedr b. Hasanveyh sülalesinden olan Sermâc Kalesi hâkiminin bu sene vefat ettiğini ve kalenin de Selçuklulardan İbrahim Yinâl'a teslim ettiğini kaydederken (İbnü'l-Esîr, 1987, VIII:278) İranlı bir tarihçimiz ise bunun Bedr b. Tahir olduğunu yazar (Ahmed Gaffarî Kâzvînî:168 ). Nitekim bu tarihte Selçuklular el-Cibâl Bölgesi’nde yer alan birçok şehri ele geçirdikleri gibi başta Büveyhiler olmak üzere bölgedeki siyasi teşekküllerin çoğunu da itaat altına almışlardı (Zahireddin Nişâpurî, 1390:18; Ravendî, 1921:104; Hüseynî, 1380:56; Bundarî, 1900:8; Ezdî, 1909:37-38; Şeref Han, 1860, I:23).

\section{SONUÇ}

Hasanveyhler hanedanı, Kürtlerin eskiden beri görülen bir bölgede, Kuzey-Batı İran'da (al-Cibâl Bölgesi’nde) 80 yıldan fazla etkili olmuşlardır. Nitekim söz konusu hanedan X. Asrın yarısından XI. asrın ilk çeyreğine kadar Batı İran'da etkin rol oynamış bir İslam hanedanıdır. Söz konusu hanedanın Büveyhiler’e bağlı olarak bölgede kurdukları özerk iktidar, Kürtlerin İslam fütuhatından sonra kurduğu ilk ve en önemli siyasi teşekküllerden biri olup dönemin kaynaklarının 1srarla vurguladıkları gibi topraklarında huzur ve güveni tam bir otorite ile sağlamışlardır. Hasanveyhler, bölgelerinde aktif bir askeri ve siyasi yaşam sürmelerinin yanında ilim, kültür ve mimari de seçkin çalışmalarda bulunmuşlardır. Bunlara ek olarak Hasanveyh liderleri hayır ve yardım konusunda da dönemlerinin önde gelen şahsiyetleri olmuşlardır. Fakat daha çok yerel güçlerle mücadele ettiklerinden ve daima Büveyhilerin baskısı altında olduklarından büyük bir siyasi teşekkül halini almadıklarına müşahede etmekteyiz.

\section{KAYNAKÇA}

Anonim, (1318). Mucmelü't-Tevarih ve Kıssas, (Tah. Melik Şuara Bahâr), Tahran.

Bundarî, (1900). Kitabü 't-Tarih Devletü al-Selcûk, Misır.

Cahen, Claude, (1986). “Hasanwayh”, $E I^{2}$, III:258-259.

Carbazekânî, Tercüme-yi Tarih-i 'Utb̂̂, Kitâbhâne-yi Meclis-i Şurâ-yı Millî, (Tahran), nr.2923.

Ebü'l Fidâ, İmaddin İsmail b. Ali, (1997). Tarihu Ebü'l-Fidâ, Muhtasar fi Ahbaru'l-Beşer, (Neşr. Mahmud Deyyub), I-II, Beyrut.

Ezdî, İbn Nizameddin el-Hüseynî, (1909). el- 'Iraziye fi Hikayetü’s-Selçukiye, (Neşr. Karl Süssheim), Leiden.

Fakîhî, Ali Asgar, (1378). Tarih Âl-Büveyh, Tahran. 
Fesaî, Hasan b. Hasan, (1367). Farsname-i Nasırî, (Neşr. Mansur Restgar Fesaî), I-II, Tahran

Hafiz Ebru, (1378). Coğrafya, (Tah. Sadık Secadî), I-III, Tahran.

Heyet, (2014). The Khalifa Collection of Islamic Coins, London.

Hidayet, Muhammed Hadi, Fihristü't-Tevarih, (1373). (Neşr. Abdulhüseyin Nevaî), Tahran

Hândmir, Gıyaseddin Muhammed, (1362). Habib-i Siyer fi Ahbarü'l-Beşer, (Neşr. Muhammed Debirsiyaki), I-IV, Tahran.

Hüseynî, Sadreddin, (1380). Zübdetü’t-Tevarih, Tahran.

İbnü’l-Belhî, (1921). Fârsnâme, (Neşr. G.Le Strange-R.A.Nicholson), London.

İbnü'l-Esîr, İzzeddin, el-Kâmil fî̀t Tarih, (1987). (Tah. Muhammed Yusuf Dakâk), I-XI, Beyrut.

İbn Haldûn, Veliyeddin Abdurrahman b. Mahmud el-Hadrami el-Magribi, (2006). Tarih İbn Haldun, Kitâb el-'íber ve Divan el-Mübtedâ ve el-Haber fi Eyyam el-'Arab ve el-'Acem ve el-Berber ve men Asarahum min zev Sultân Ekber, I-VIII, Beyrut.

İbnü'l-Kesîr,(1995). El-Bidaye ve'n-Nihaye, (Çev. Mehmet Keskin), I-XV, İstanbul.

İbn Miskeveyh, (2003). Tecâribü'l-Umam, (Tah. Seyid Kesrevî), I-V,Beyrut.

İbn Mustevfi, (1980). Tarih-i Erbil, I-II, Irak.

İbn Tagrîbirdî, (1992). Nucûm ez-Zâhire fi Mulûk Misr ve'l- Kahire, (Tah. Muhammed Hüseyin Şemseddin), I-XVI, Beyrut. İbnü'l-Verdî, Zeyneddin Ömer b. Muzaffer, (1996) .Tarih İbn Verdî, Tetimmet'ül Muhtasar fi Ahbaru'l-Beşer, I-II, Beyrut. İsfehânî, Ebü Naim, (1990). Tarih-i İsbehân, (Tah. Seyd Kesrevî), Beyrut.

Katib Çelebî, (1376). Takvimü't-Tevarih, (Fars. Çev. Mir-Haşim Muhaddis), Tahran.

Kâzvînî, Kadı Ahmed Gaffarî, Tarih-i Cihân Ârâ, Tahran tz.

Kâzvinî, Zekeriya b. Muhammed, (1373). Asaru'l-Bilad ve Ahbaru'l-İbad, (Fars. Çev. Mirza Cihangir Kaçar), Tahran.

Kirmânî, Afdaladdin, (1373). Selçukıyân Guz der Kirmân, (Tah.Muhammed İbrahim), Tahran.

Kumî, Hasan b. Muhammed, (1385). Tarih-i Kum, (Fars. Çev. Taceddin Hasan Hatîb), Kum.

Mustevfî, Hamdullah, (1387). Tarih-i Guzide, (Tah. Abdulhüseyin Nevaî), Tahran.

Müneccimbaşı, (1285). Sahâifül'-Ahbâr, II, İstanbul.

Ravendî, (1921). Rahatu's-Sudur ve Ayetü's-Surur, (Neşr. M.İkbal), London.

Reşîdu'd-dîn, Fazlullah Hemedânî, (1386). Câmi “ üt-Tevârîh, Tarih-i Sâmâniyyân ve Büveyhiyân ve Gaznuyân, (Neşr. Muhammed Ruşen), Tahran.

Ruhanî, Macid Merduh, (1371). Meşahirü'l-Kürd, Tahran.

Rûzravârî, (2003). Zeyl Tecâribü'l-Umam (Tah. Seyid Kesrevî), VI, Beyrut.

Şeref Han, (1860). Şerefnâme- Histoire des Kourdes, (Neşr. V. Véliaminof -Zernof), I-II, St-Pétersbourg.

Tatavî, Ahmed b. Nasrullah, (1382). Tarih-i Elfî, (Tah. Alemrıza Tabâtbâyi), I-VIII, Tahran.

Utbî, Kitabu'l-Yemînî, (1858). (İng. Çev. James Reynolds), London.

Vassaf, (1383). Tahrir Tarih-i Vassaf (Haz. Muhammed Ayeti), Tahran.

Yasmî, Reşîd, Kürd: Peyvesteki Nijad ve Tarihe o, Tahran tz.

Yakut el-Hamavî, (1988). Mucemu'l-Büldan, I-V, Beyrut.

Zahireddin Nişâpurî, (1390) . Selçukname, (Tah. İsmail Avşar), Tahran.

Zerkub-1 Şirazî, (1350). Şirazname, (Tah. İsmail Vaiz Cevadî), Tahran. 